\title{
A NEW ANGIOSPERMIC PETRIFIED FOSSIL WOOD FROM THE DECCAN INTERTRAPEAN BEDS OF JAMSAVLI M.P. INDIA.
}

\author{
MESHRAM S. M⒈, MOHATURE V.M ${ }^{2}$., PANDEY I ${ }^{3}$., NARKHEDE S.D. ${ }^{4}$ \\ ${ }^{1}$ Manoharbhai Patel College of Art, Commerce and Science Sakoli. Dist. Bhandara. MS \\ ${ }^{2}$ Rashtrapita Mahatma Gandhi Art, Science College Nagbhir, Chandrapur \\ ${ }^{3}$ C.J.Patel College of Art, Commerce and Science College Tirora. Dist.Gondia. MS \\ ${ }^{4}$ Department of Botany, Institute of science Nagpur M.S. \\ Corresponding author email: Sanjaymeshram83@rediffmail.com, ipandey1974@gmail.com
}

\begin{abstract}
:
A well preserved dicot wood was collected from Jamsavali M.P. The wood is dicotyledonous, diffuse porous, vessels mostly solitary and in radial multiples of two. Perforation plate simple. Intervascular pit pairs alternate, bordered, parenchyma paratracheal, vascicentric, wood rays mostly multiseriate and composed of heterogeneous cells, uniseriate rays mostly homogenous. Fiberes short, thin walled, nonseptate. The wood though shows some characters of the present day families like Dipterocarpaceae, Lecythidaceae, Connaraceae, Flacaurtiaceae, Lythraceae and Bombacaceae. It has close affinities with the members of the family Bombacaceae. It could not conclusively be traced to any particular genus but it broadly placed under the family Bombacaceae.
\end{abstract}

Key words: - Dicot wood, diffuse porous, ray multiseriate, Bombacaceae.

\section{INTRODUCTION:}

Recent developments have provided a better understanding of the history, evolution and relationships of the angiosperms. In addition, the fossil record, as representative of the history of life, holds the potential for clarifying relationships among extant taxa by revealing extinct mosaic taxa that link modern ones, in addition to providing the general pattern of evolution of taxa through time. Historically, and in the context of evolutionary biology, the fossil record has played both informative and corroborative roles and continues to be called upon to do both. However, the advent of modern methodologies for comparative studies of extant taxa invites a reassessment of the primacy and scope of the fossil record in addressing questions of evolution and systematic relationships (William L.2004). The wood being comparatively more resistant than the other plant parts is often better preserved depending on the extent of degradation of cellulose layers of cell wall. Some notable fossil woods reported from Deccan Intertrappean beds of India. Simarubaceoxylon mahurzari and Barringtonioxylon deccanese (Shallom, 1959); Polyalthioxylon parapaniense (Bande, 1973); Ebenoxylon mohgaonse (Chitaley and Patil, 1972); Syzygioxylon mandlaense (Ingle, 1973); Rhamnoxylon intertrappea (Chitaley and Kate, 1971).Lagerstoemioxylon vasicentricum, Lagerstoemioxylo eoflosregium, Lagerstoemioxylo harsolavense, Lagerstoemioxylo obliqueporantum Lagerstoemioxylo eohypolucu, Lagerstoemioxylo royi, Lagerstoemioxylo parenchymatosum, Lagerstoemioxylo floribunda, Lagerstoemioxylo eohypolucum (Harsh and Sharma 1995), Lythreceoxylon jabalpurii ( Meshram 2014), Meliaceoxylon jabalpurii (Meshram 2016). 
The fossil wood has been collected from the fossiliferous locality of Deccan Intertrappean series of M.P. This petrified material is well preserved, black brown in color and rough in texture. It has yielded fairly good peels.

\section{MATERIAL AND METHODS:-}

The material was thoroughly ground to make the surface even. It was etched with Hydrofluoric acid and washed under running water. Peels were then taken out and slides were prepared. These were studied under the microscope and camera Lucida sketches were drawn.

Description: The wood is diffused porous, decorticated without any growth rings. Vessels are not visible to the naked eye. The anatomical study of this fossil wood is done with the help of available literature on anatomy and living section. (Esau 1965, Fahn 1989, Eames and MacDaniels 1972) The anatomical study is categorized as follows.

Vessels: They are predominantly solitary and in tangential or in radial multiples of two or three also (Plate 1, Fig 1). These are small to moderate in size with the diameter varying between $215 \mu \mathrm{m}$ and $220 \mu \mathrm{m}$.The vessel frequency is 15 to $19 \mathrm{sq} / \mathrm{mm}$. The vessel member length varies from $310 \mu \mathrm{m}$ and $390 \mu$ (Plate 1, fig 4). Perforation plates are simple, mostly horizontal or oblique (Plate1 Fig 4). Vessels are thick walled without any tyloses. They are associated with wood rays contiguous on either side. Intervascular bordered pits are very distinct. They are thick walled, alternate and the pit pores are generally elliptical with the diameter varying between $24 \mu \mathrm{m}$ to $35 \mu \mathrm{m}$ (Plate 1 Fig 4 ).

Parenchyma: Parenchyma is well preserved. It is pentagonal to hexagonal in shape and in single layer. Paratracheal vasicentric parenchyma forms a single layered sheath around the vessels (Text Fig 4; Plate 1 Fig 2).

Wood Rays: The wood rays are uniseriate moderately numerous but some are multiseriate. It is 9 to 13 cells in height, homogenous, with of procumbent cells. The height and diameter vary between $520 \mu \mathrm{m}$ to $580 \mu \mathrm{m}$ and $120 \mu \mathrm{m}$ to $130 \mu \mathrm{m}$ respectively (Plate1 Fig 5-6).

Fibres: Fibers are abundant forming the ground mass of the wood. They are thin walled and are compactly arranged in radial rows between the rays without any intercellular space. (Text Fig 7; Plate 1, fig 5-6). Fibre cells are non septate. They measure $25 \mu \mathrm{m}$ in height and $15 \mu \mathrm{m}$ in diameter.

\section{RESULTS AND DISCUSSION}

Xylem parenchyma, xylem rays and the diffuse porous nature of the vessels along with the intervascular pit pairs are the distinguishing characters of the fossil. The studied fossil was compared with earlier reported fossil woods from the various localities.

In Barringtonioxylon deccanense (Shallom, 1959), vessels are with radial and tangential diameters varying from 100-150 $\mu$ and 78- $100 \mu$ respectively; mostly in radial rows of two and three, angular tyloses present; vessel segments 200-400 $\mu$; intervessels pits alternate, diameter varying from 11-14 $\mu$. Parenchyma was abundant in part scattered and mostly as uniseriate lines joining two adjacent rays. Uniseriate rays fairly abundant. Fibres non-libriform; non-septate. Hence present fossil is different.

In Ebenoxylon mohgaonse (Chitley \& Patil, 1972), wood was diffuse porous, vessels 40-45 per sq. mm.; solitary or in radial groups of $2-5$, oval to rounded in tangential diameter and $38.62 \mu$, radial diameter 38-69 $\mu$; vessel segments $200-250 \mu$ long; perforations simple; intervessel pits bordered, alternate, hexagonal, contiguous and 4-5 $\mu$ in diameter. Protoxylem with spiral and metaxylem with reticulate and pitted thickening. Parenchyma paratracheal and diffuse. So, differs from the fossil under study in all the characters.

Syzygioxylon mandlaense (S. R. Ingle, 1973), Rhamnoxylan intertrappea (Chitaley \& Kate, 1971), Polyalthoxylon parapaniense (Bande, 1973), differs from the present wood mostly in the 
anatomical characters with respect to the vessels number frequency and nature of parenchyma.

Lagerstoemioxylon vasicentricum, (Harsh and Sharma 1995) rays are mostly uni to biseriate, small to large and homo to heterogeneous rays, vessels small, vasicentric parenchyma. Present wood shows uniseriate to multiceriate ray therefore it is different.

Lagerstoemioxylo eoflosregium, (Harsh and Sharma 1995) wood semirinf, porous, growth ring distinct, vessels large, 7-9 cell wide band of initial parenchyma and thick walled fibres. vessels solitary, arrangement in distinct tangential lines, tyloses absent, paratracheal parenchyma almost aliform but at growth ring in the form of 8-12 cells wide bands. Rays are uniseriate rarely biseriate, almost homogenous consist of procumbent cells with an average height of 66.6 to $747.8 \mu$ in length fibres commonly septate with crystals. Present wood shows uniseriate to multiceriate ray and crystal absent therefore it is different.

Lagerstoemioxylo harsolavense (Harsh and Sharma 1995) wood semiring porous, growth ring present, demarcated larger early wood pores, perforation plate simple, apotracheal diffuse to zonet in short bands, xylem rays exclusively uniseriate 4 to 15 cell high, measuring 106 to 565 micron in length, homogenous, fibre septed having crystles. Present wood shows predominantly solitary vessels; uniseriate to multiceriate ray therefore it is different.

Lagerstoemioxylo obliqueporantum (Harsh and Sharma 1995) wood partial semiring porous, growth ring present, delimated by little larger vessels, change in vessels size almost negligible giving an impression of a diffused porosity, vessels large, oval, tangential diameter, 179 to 183 micron and radial 293 to 301 micron meter, exclusively solitary, arrangement obliquely, perforation plate simple, palatracheal parenchyma vececentric, aliform to oblique confluent with 4 to 9 vessels, apotracheal prominent as solitary cells, xylem rays exclusively uniseriate, mostly heterogenous with 1 to2 upright cell per rays, crystals present. Present wood shows uniseriate to multiceriate ray with 10 to 15 cells in height therefore it is different.

Lagerstoemioxylo eohypolucum, (Harsh and Sharma 1995) wood typically ring porous, growth ring present demarcated by larger vessels inclosed in wide bands of parenchyma and thick walled fibre zone, vessels narrow oval, exclusively solitary, arrangement only in tangential lines, parenchyma paratracheal and apotracheal, paratracheal mostly aliform to aliform confluent forming 6 to 8 cells wide bands, apotracheal diffuse, rarely zonate of 5 to 10 cells, xylem rays- exclusively uniseriate, $3-27$ high, mostly homogeneous, procumbent cells $27 \mu$ in average length, frequency 18 to $21 / \mathrm{mm}^{2}$, fibresseptate with crystals. Present wood shows uniseriate to multiceriate ray with 10 to 15 cells in height therefore it is different.

Lagerstoemioxylo royi, (Harsh and Sharma 1995) wood semi ring porous with a tendency towards diffuse porosity, growth ring distinct, delimited by dark thick walled fibres and an initial parenchyma band of 3-4 cells width, vessel-moderately small to large, oval, solitary, perforation plate simple, end wall transverse, xylem rays- exclusively uniseriate, 4 to 19 cells high, fibres septate, crystals present. Present wood shows uniseriate to multiceriate ray with 10 to 15 cells in height therefore it is different.

Lagerstoemioxylo parenchymatosum, (Harsh and Sharma 1995) wood ring porous, growth rings distinct, larger vessels, circular to oval, paratracheal parenchyma, mostly aliform, xylem rays exclusively uniseriate $2-50$ cell in hight. Present wood shows solitary vessels; uniseriate to multiceriate ray with 10 to 15 cells in height therefore it is different.

Lagerstoemioxylo floribunda, (Harsh and Sharma 1995) wood semi ring porous, growth rings distinct, delimited by larger vessels, thick walled fibres and interrupted terminal parenchyma, vessels extremely small to large, perforation plate simple with oblique end walls, inter vessel pits opposite and angular parenchyma paratracheal 
and terminal, vesicentric, xylem rays mostly uniseriate, rarely biseriate, fibres septate with crystals. Present wood shows uniseriate to multiceriate ray with 9 to 13 cells in height therefore it is different.

Lythreceoxylon jabalpurii Vessels predominantly solitary and also in radial and tangential multiples of 2 or 3 . Vessel diameter varies between $220 \mu m$ to $225 \mu \mathrm{m}$, frequency 18 to $21 \mathrm{sq} / \mathrm{mm}$., member length varies between $320 \mu \mathrm{m}$ to $400 \mu \mathrm{m}$. Intervascular pit pairs alternate, pore elliptical, and diameter $30 \mu \mathrm{m}$ to $40 \mu \mathrm{m}$. Parenchyma scanty, paratracheal vescicentric. Rays mostly multiseriate and uniseriate. Multiseriate rays are homo to heterogeneous, 10 to 15 cells high, uniseriate rays are homogeneous, and 4 to10 cell high. Fibres nonseptet, non-storied $27 \mu \mathrm{m}$ in height and $16 \mu \mathrm{m}$ in diameter. But present fossil shows many differences like vessels, fibbers, wood parenchyma, therefore its is different wood.

Meliaceoxylon jabalpurii Vessels predominantly solitary and also in radial and tangential multiples of 2 or 3 . Vessel diameter varies between $210 \mu \mathrm{m}$ to $215 \mu \mathrm{m}$, frequency 15 to $20 \mathrm{sq} / \mathrm{mm}$.,member length varies between $310 \mu \mathrm{m}$ to $380 \mu \mathrm{m}$. Intervascular pit pairs alternate, pore elliptical, and diameter $25 \mu \mathrm{m}$ to $30 \mu \mathrm{m}$.

Thus no appreciable affinities were observed between the earlier reported wood fossil with the present one. Accordingly, the modern day families were explored to place the wood fossil under any one of them.

Comparisons with the modern families with living section have shown that the fossil wood has some similarities with families like Lecythidaceae, Dipterocarpaceae, Connaraceae, Flacaurtiaceae Lythraceae and Bombacaceae (Metcalfe and Chalk 1950).

The family Dipterocarpaceae, although agreeing with the fossil in certain general characters like vessel usually medium sized, exclusively solitary or in multiples of 2 or 3 cells, perforation plate simple, intervascular pitting alternate, But it differs, sharply from the given fossil in the arrangement of parenchyma, In Dipterocarpaceae, parenchyma is usually abundant and includes both paratracheal and apotracheal types, whereas in the studied fossil the parenchyma arrangement is paratracheal vesicentric.

The family Lecythidaceae, although agreeing with fossil in certain characters like perforation simple and intervascular pitting alternate but it differs sharply from the given fossil in the arrangement of vessels and presence of parenchyma. In Lecythidaceae, parenchyma is in typical apotracheal bands whereas in the studied fossil vessels are medium sized and parenchyma is ample and the arrangement is typically paratracheal vasicentric.

The present fossil wood differs from wood of Flacaurtiaceae in nature of parenchyma.In Flacaurtiaceae parenchyma is mostly absent or very sparse, and when present usually limited to isolated cells touching the vessels (Metcalfe and Chalk, 1950).

The fossil wood differs from Connaraceae because in Connaraceae vessels are large (more than $200 \mu$ ) with simple pitting whereas in this fossil wood vessels are medium sized with bordered pitting.

In Bombacaceae , wood partial semiring porous, growth ring present, delimited by little larger vessels, change in vessels size almost negligible giving an impression of a diffused porosity, vessels large, oval, tangential diameter, exclusively solitary, arrangement obliquely, perforation plate simple, paratracheal, parenchyma, vececentric, aliform to oblique confluent with 4 to 9 vessels, apotracheal prominent as solitary cells, xylem rays uniseriate to multiseriate, mostly heterogenous with height 2 to50 cell per rays. Present wood shows resemblances in xylem rays uniseriate to multiceriate with 7 to 15 cells in height.

On the above discussion it is clear that fossil wood resemblance only Bombacaceae.like vessels nature, perforation plate simple, palatracheal parenchyma, vecicentric, xylem rays exclusively 
uniseriate, mostly heterogenous with height 2 to 50 cell per rays

From the above discussion it can be concluded that present fossil wood is different from living genera, on basis of certain anatomical characters. It resembles the family, on certain general characters, thus it is placed under the family Bombacaceae; hence it is named as Bombacaceaeoxylon jamsavlii gen. et. sp. nov. The generic name is after the family Bombacaceae and the specific name is after the locality Jamsavali from where the sample was collected.

\section{Diagnosis:}

Bombacaceaexylon jamsavlii gen.nov.

Wood, dicotyledonous, diffuse porous, vessels mostly solitary and in radial multiples of two. Perforation plate simple. Intervascular pit pairs alternate, bordered, parenchyma paratracheal, vascicentric, wood rays mostly multiseriate and composed of heterogeneous cells, uniseriate rays mostly homogenous. Fiberes short, thin walled, nonseptate.

Bombacaceaexylon jamsavlii gen. et. sp. nov. Vessels predominantly solitary and also in radial and tangential multiples of 2 or 3 . Vessel diameter varies between $215 \mu \mathrm{m}$ to $220 \mu \mathrm{m}$, frequency 15 to $19 \mathrm{sq} / \mathrm{mm}$., member length varies between $310 \mu \mathrm{m}$ to $390 \mu \mathrm{m}$. Intervascular pit pairs alternate, pore elliptical, and diameter $24 \mu \mathrm{m}$ to $35 \mu \mathrm{m}$. Parenchyma scanty, paratracheal vescicentric. Rays mostly multiseriate and uniseriate. Multiseriate rays are homo to heterogeneous, 9 to 13 cells high, uniseriate rays are homogeneous, and 4 to 10 cell high. Fibres nonseptet, non-storied $25 \mu \mathrm{m}$ in height and $15 \mu \mathrm{m}$ in diameter.

Holotype: SMM/ ANG.W4/ Deposited at Department of Botany, Institute of Science, Nagpur

Locality : Jamsavli

Horizon : Deccan Intertrappean Series of India .

Age : ? Upper Cretaceous.

\section{REFERENCES:-}

Bande, M B. 1973. A petrified dicotyledonous wood from the Deccan Intertrappean beds of Mandla dist. The Botanique 4(1): 41-48

Chitalay, S. D. and Kate, V. R. 1971. A petrified Rhamnaceous wood from the Deccan Intertrappean beds of Mohgaonkalan Botanique 3 (1): 41-44.

Chitalay, S. D. and Patil, G. V. 1972. An ebenaceous fossil wood infected with deuteromyceteous fungus from the Deccan Intertrappean beds of India. The Botanique 3 (2): 99-105.

Cooke, C. I. E. 1958-67. The Flora of the Presidency of Bombay. Botanical Survey of India, Calcutta.

Duvall, C.S., 2011. Ceiba pentandra (L.) Gaertn. In: Brink, M. \& Achigan-Dako, E.G. (Editors). PROTA (Plant Resources of Tropical Africa / Ressources végétales de l'Afrique tropicale), Wageningen, Netherlands. Accessed 28 January 2020.

Eams, A. J. and MacDaniels 1972. Morphology of Vascular plants (1961) Tata Macgrow- Hill

Esau, K. 1965. Plant Anatomy John Wiely \& Sons New York.

Fahn A. J. 1989. Plant anatomy Pergamon Press, Sydeny

Harsh R. and Sharma B. D. 1995. Petrified tertiary wood from Bikaner (Rajastan). Indian Journal of Earth Sciences, Vol.22, No.3, pp.104-109

Hutchinson, J. 1959. The Families of Flowering Plants Koeniqstein

Ingle, S. R. 1973. Syzygioxylon mandlaense gen.et.sp.nov.A fossil dicotyledonous wood from Deccan Intertrappean beds of Mohgaonkalan, M.P., India.

Mandla dist. of M.P. India. The Botanique 4(1): 71-76.

Metcalfe, C. R. and Chalk 1950. Anatomy of Dicotyledons. Vol, I \& II Oxford Chalk, L. University press, Oxford 
Meshram S,M. 2014, Report on fossil wood from the Deccan Intertrapean Beds of Jabalpur, M.P. India. Int. J. of Life Sciences, 2014, Vol. 2(4): $311-317$

Meshram S,M. 2016, Report on fossil wood from the Deccan Intertrapean Beds of Jabalpur, M.P. India. ISSN No. 2394-8426 With International Impact Factor 2.254, National Seminar On Recent Trends In Life Sciences \& Materials Science, 14th \& 15th Mar2016.

Sint, Khin \& Adamopoulos, Stergios \& Koch, Gerald \& Hapla, Franti $\AA_{j}$ ek \& Militz, Holger. (2012).
Wood Anatomy and Topochemistry of Bombax ceiba L. and Bombax insigne Wall.. BioResources.

8. 10.15376/biores.8.1.530-544

Shallom, L. J. 1959. A fossil dicot wood from the Deccan Intertrappean Beds of Mahurzari. J. India. bot. Soc. 37 (2): 492-498.

William L. 2004. Fossil evidence and Phylogeny: The Age of major Angiosperm Clades based on Mesofossil and Macrofossil evidence from cretaceous American Journal of Botany 91(10):1666-1682. 2004. 
Plate fig. shows Living section (T.S. And T.L.S.) Of Family Bombacaceae, Dipterocarpaceae \& Connaraceae

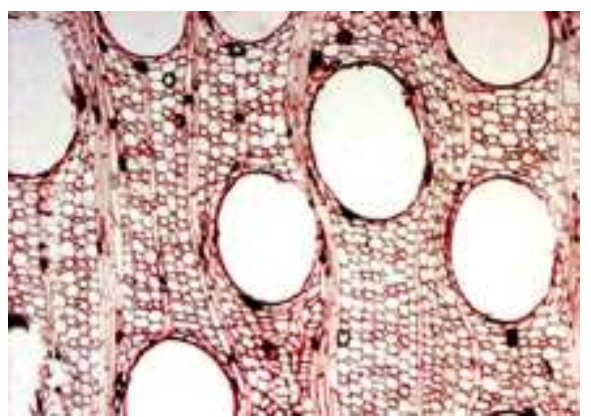

1, T.S. of wood in Bombacaceae (by Duvall, C.S., 2011)

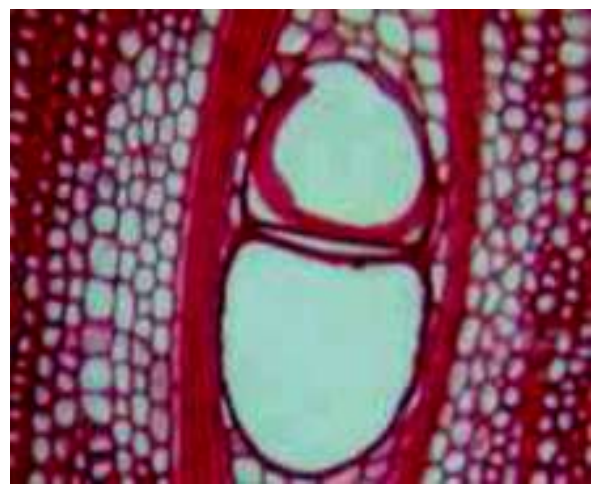

1, T.S. of wood in Dipterocarpaceae

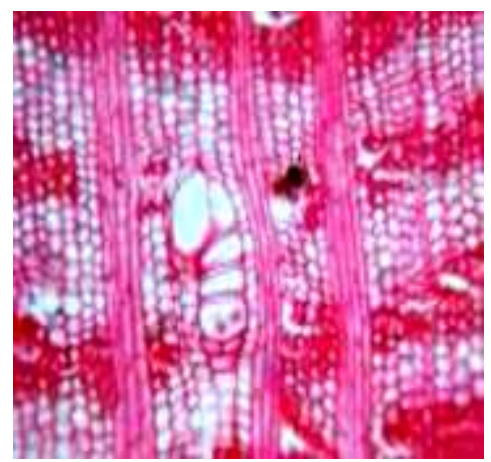

1, T.S. of wood in Connaraceae

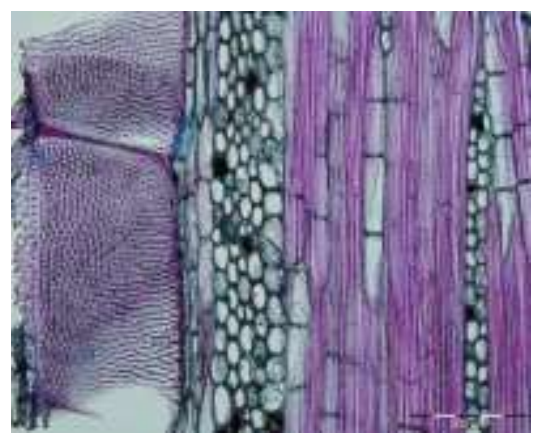

2, T.L.S. of wood in Bombacaceae( By Sint, Khin et.al)

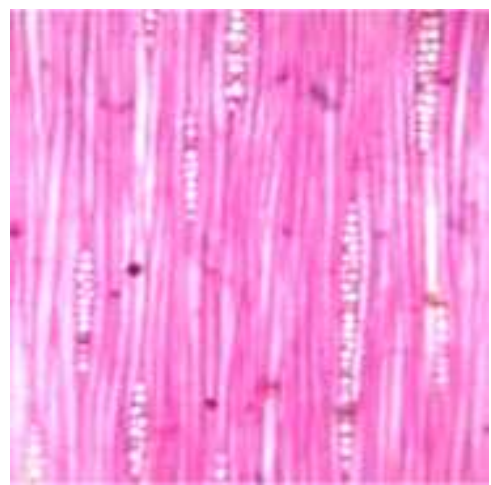

2, T.L.S. of wood in Dipterocarpaceae

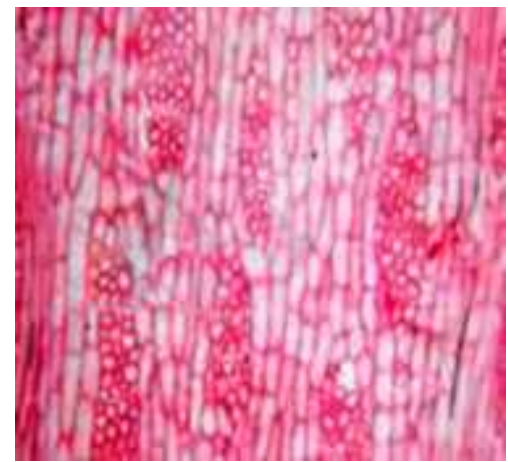

2, T.L.S. of wood in Connaraceae

Explanation of Plate 1, Figs. 1-6

Fig. 1: T.S of wood showing solitary or less in multiple of two vessels, Fig. 2: T.L.S of wood showing triseriate medullary rays, Fig. 3: R.L.S of wood showing homogenous medullary rays, Fig. 4:Solitary, vessels surrounded by paratracheal vasicentric parenchyma.

Fig. 5: Intervessel alternate pitting magnified, perforation plate simple obliquely placed. Fig. 6: Uniseriate and multiseriate wood ray. 
I J R B A T, Issue (VIII), Vol. I, Jan 2020: 27-33

A Double Blind Peer Reviewed Journal

OPEN $\bigcirc$ ACCESS

e-ISSN 2347 - 517X

Original Article

Pate 1 Figs.1- 6 (Bombacaceaeoxylon jamsavlli)

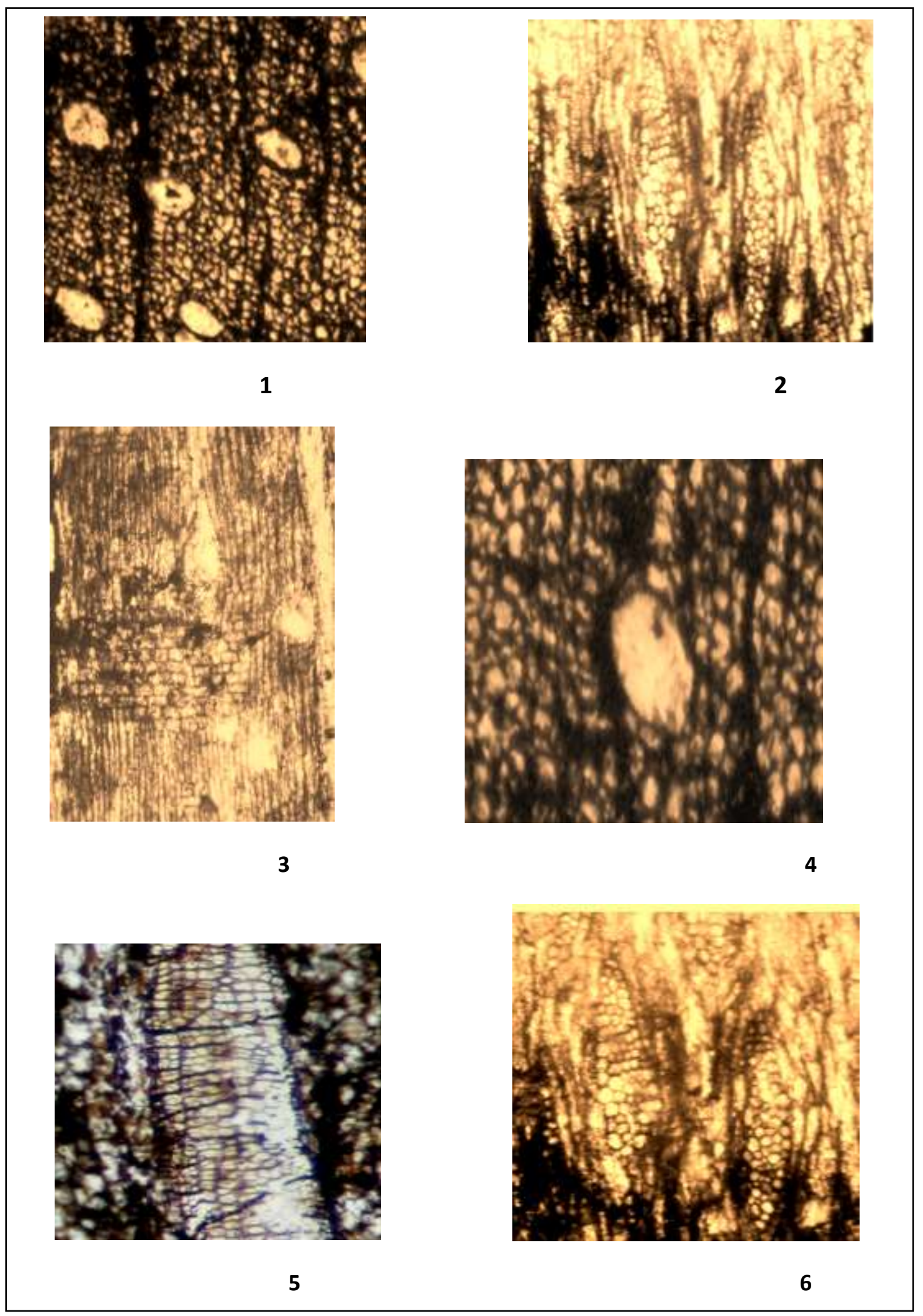

$\underset{\substack{+0 \\ 0 \\ 0}}{\infty}$ 